Gynacantha is a dragonfly genus with 87 species distributed throughout the world, especially in the tropics and subtropics (Asahina 1993; Schorr \& Paulson 2009). Among them about 30 species are OPEN ACCESS known from the Southeastern Asia. Dragonflies of the genus are large in size, pale brown and green in color and are crepuscular by nature (Fraser 1936). Till date, one species, Gynacantha hyalina Selys, 1882 has been recorded from Bangladesh (Chowdhury \& Mohiuddin 2011).

Materials examined: Two males were collected by the author on 25 October 2014 from Tilagor Eco Park $\left(24^{\circ} 54^{\prime} 49.0^{\prime \prime} \mathrm{N} \& 91^{\circ} 54^{\prime} 14.2^{\prime \prime} \mathrm{E}\right)$. The dragonflies were perching in the shade of the bush while they were photographed and later captured using an insect sweeping net. The specimens are deposited in the Department of Biochemistry and Molecular Biology, Shahjalal University of Science and Technology, Sylhet (BMBZO-ODO-002 and BMBZO-ODO-003).

Measurements: Abdomen: $29 \mathrm{~mm}$ (including anal appendages); anal appendage: $6-6.5 \mathrm{~mm}$; hind wing: 21-22 mm.

Description: Head pale olivaceous brown, eyes dark brown. ' $T$ '-shaped black mark with bold stem distinctly present on the upper surface of the frons (Images 1-3). Thorax brown, distinct stripe absent on sides. Legs brown, distal end of the femora darkened. Wings transparent,

\section{GYNACANTHA SUBINTERRUPTA RAMBUR, 1842: AN ADDITION TO THE ODONATES (INSECTA: OdonAtA: AESHNIDAE) OF BANGLADESH}

\section{Kawsar Khan}

Department of Biochemistry and Molecular Biology, Shahjalal University of Science and Technology, Bangladesh kawsarkhan-bmb@sust.edu

veins brownish. Brown rays present in the subcostal and cubital spaces of forewing and hindwing. Pterostigma pale brown to golden, three millimeters in length and covering three to four cells. Discoidal of forewings and hindwings are six-celled and five-celled respectively, basal cell divided into two cells; six nerves traversing hypertrigones of forewings and hindwings. Seven cubitas nerve in forewings, six in the hindwings. Anal loop oval-shaped, consists of 13 cells. Nodal index: 18$25 / 25-18$ in forewings and $21-18 / 19-21$ in hindwings. First and second abdominal segments swollen, third segment strongly constricted and elongated, segments 8-10 are narrow and cylindrical, color is blackish-brown. Caudal appendages are brownish; the superior long and straight, basal one-fifth is narrow, the next two-fifth is swollen slightly and uniformly and the terminal two-fifth is more broadened. The apical end is sharply pointed and directed posteriorly. The inferior appendages
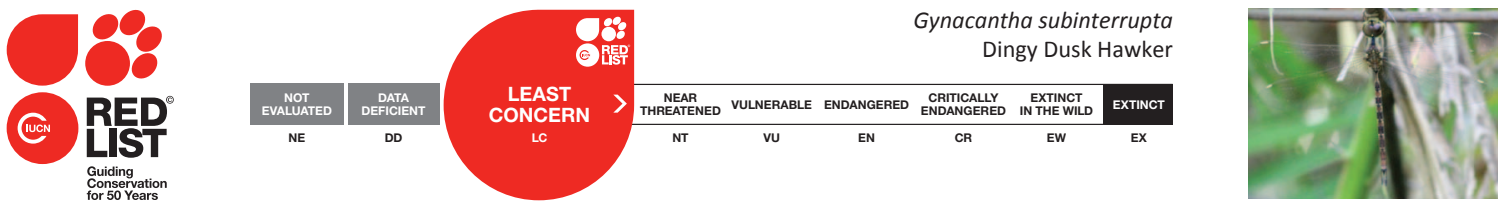

DOI: http://dx.doi.org/10.11609/JoTT.o4276.7704-5 | ZooBank: urn:Isid:zoobank.org:pub:ABB5132C-5A3D-4612-8E2A-6F7FFD56BECF

Editor: K.A. Subramanian, Zoological Survey of India, Kolkata, India.

Date of publication: 26 August 2015 (online \& print)

Manuscript details: Ms \# 04276 | Received 19 December 2014 | Final received 04 May 2015 | Finally accepted 20 July 2015

Citation: Khan, M.K. (2015). Gynacantha subinterrupta Rambur, 1842: an addition to the odonates (Insecta: Odonata: Aeshnidae) of Bangladesh. Journal of Threatened Taxa 7(10): 7704-7705; http://dx.doi.org/10.11609/JoTT.04276.7704-5

Copyright: (C) Khan 2015. Creative Commons Attribution 4.0 International License. JoTT allows unrestricted use of this article in any medium, reproduction and distribution by providing adequate credit to the authors and the source of publication.

Funding: Self funded.

Competing interests: The author declares no competing interests.

Acknowledgements: The author is thankful to Noppadon Makdum for his valuable suggestions during the study period and manuscript preparation. 

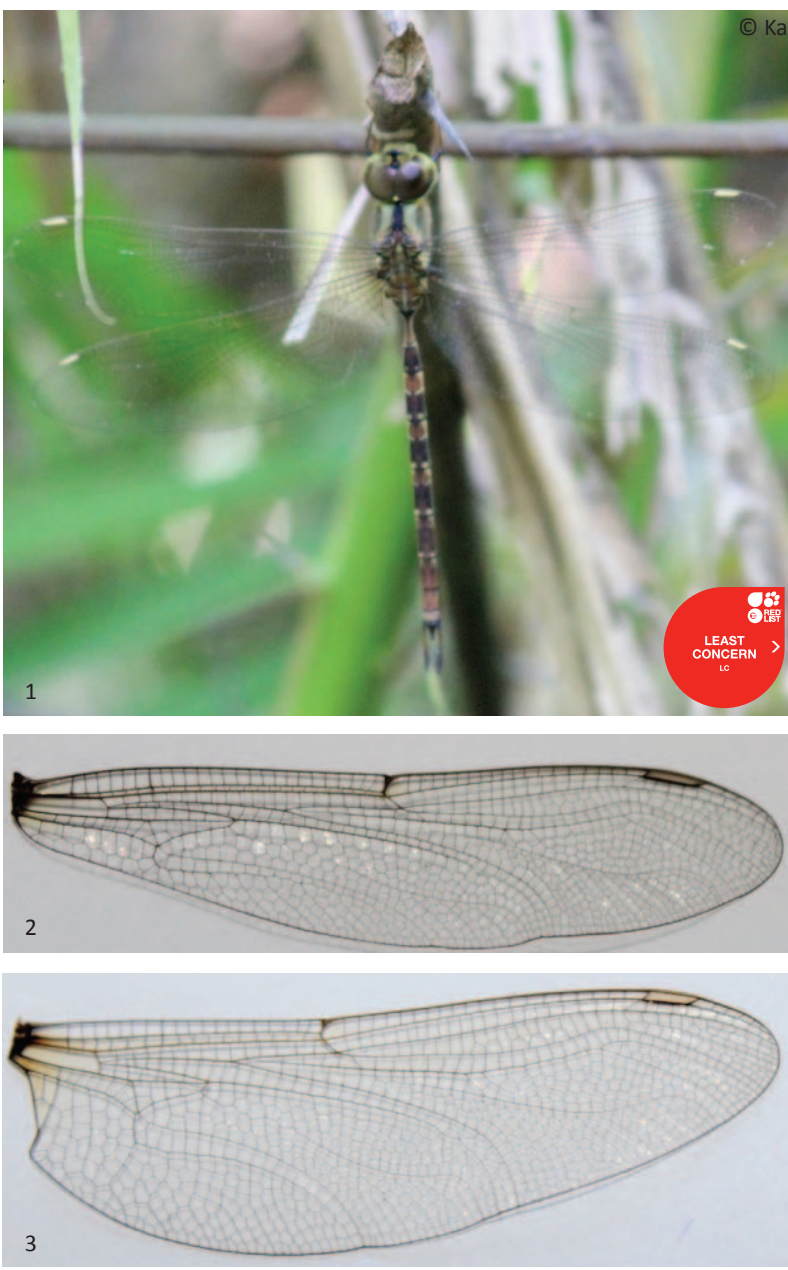
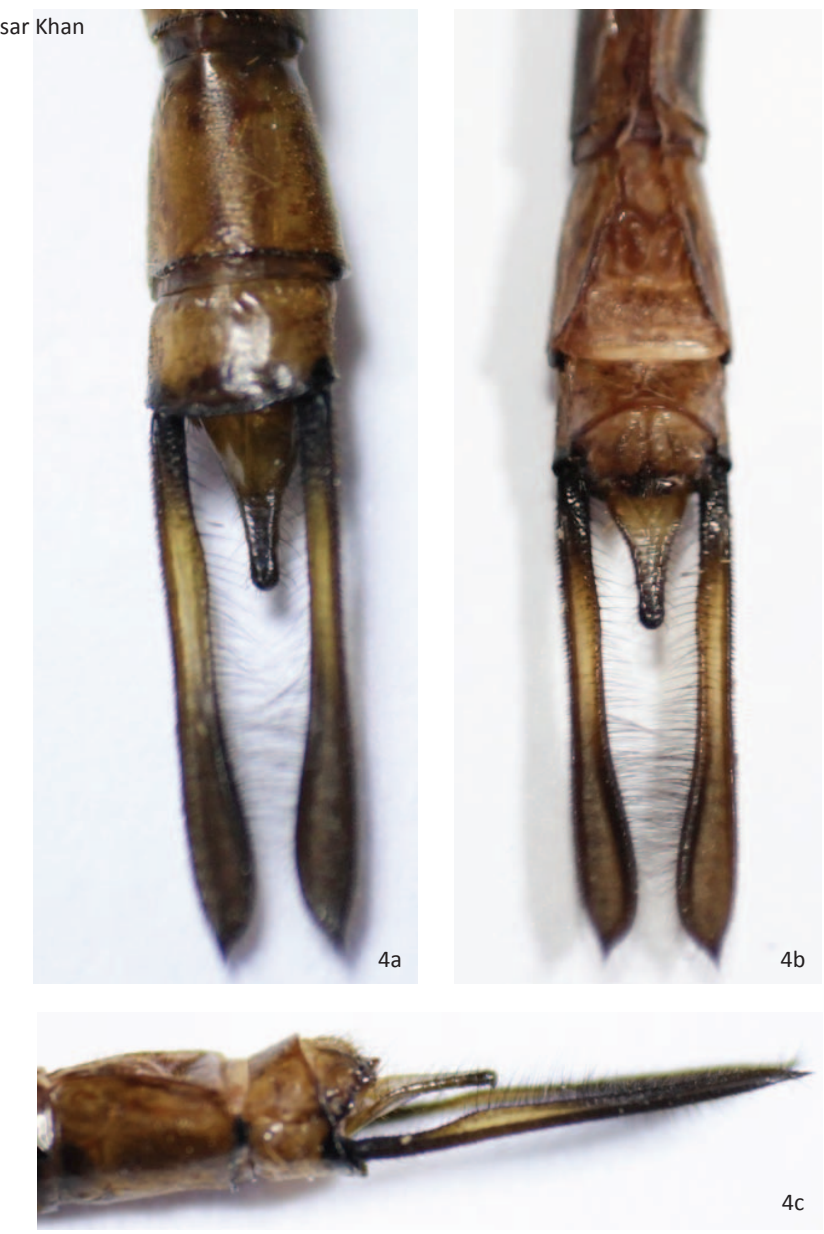

Image 1-4. Gynacantha subinterrupta Rambur, 1842

1 - Dorsal view; 2 - Right fore wing; 3 - Right hind wing; 4a - Male anal appendages dorsal view, 4b - Male anal appendages ventral view, $4 c$ - Male anal appendages lateral view

are short (1.8-1.9 $\mathrm{mm})$ and less than one third of the superior (Image 4a-c).

Discussion: Gynacantha subinterrupta Rambur, 1842 is widely distributed in southern Asia and known from Cambodia, China, India, Indonesia, Malaysia, Myanmar, Nepal, Singapore, Thailand and Viet Nam (Manh 2011). Fraser (1936) used the relative length of the superior and inferior anal appendages to differentiate Gynacantha subinterrupta from Gynacantha hyalina. The inferior is less than one-third of the superior in the former and more than one-third in the latter species. The specimen agrees well with the identification features of G. subinterrupta. The current record is not only a new national record but also extends the distribution of this species to Bangladesh. The present report also suggests there are more species waiting to be discovered and extensive survey throughout the country is required to annotate the complete checklist of the dragonflies of Bangladesh.

\section{References}

Asahina, S. (1993). A List of the Odonata from Thailand: Parts I-XXI. Bosco Offset, Bangkok, 460pp.

Chowdhury, S.H. \& M. Mohiuddin (2011). A check-list of the Odonta from the eastern region of Bangladesh with some taxonomic notes. University Journal of Zoology, Rajshahi University 30: 61-66.

Fraser, F.C. (1936). The Fauna of British India including Ceylon and Burma: Odonata, Volume 3. Taylor and Francis Ltd., London, 461pp. Manh, C.D. (2011). Gynacantha subinterrupta. The IUCN Red List of Threatened Species. Version 2014.2. <www.iucnredlist.org>. Downloaded on 04 November 2014.

Schorr, M. \& D. Paulson (2009). World Odonata List. http://www. pugetsound.edu/x6140.xml. Accessed on 09/11/2013. 